\title{
Identity as Shortcut to access Power of West Papua
}

\author{
Marlon Arthur Huwae \\ Department of Anthropology \\ Universitas Papua \\ Manokwari, Indonesia \\ Marlonarthurhuwae@outlook.com
}

\author{
Adolof Ronsumbre \\ Department of Anthropology \\ Universitas Papua \\ Manokwari, Indonesia
}

\begin{abstract}
Identity as West Papuans used to be associated with physical appearance and surname. It is not politically debated until the implementation of Special Autonomy Law in 2001. The study aimed to analize about importance to be natives of Papua is highlighted. As the laws give prioritization to the natives of Papua, the status of Sougb and Wepu as the natives is questioned as they are migrants in Sougb Jaya District. In fact, Sougb and Wepu clan have inter-marriage with local clan (Wamesa) in many decades. Accordingly. They also have shifted their strategy and social engagement, they have social capital to reproduce and to maintain their identity as the natives of Sougb Jaya. The reproduction of identity is carefully executed by the change of the district name, recreation and reproduction of myth about nativity, conflict, and control over the village by appointing the leader of Sougb and Wepu clan as the village leader. In order to minimize conflict in Kaprus and other regions in West Papua, several strategies and recommendation are proposed. These include the omitting of the term "Orang Asli" (indigenous people) and the implementation of sustainable development model namely "sustainable development plus"
\end{abstract}

Keywords-Identity reproduction; Ethnocentrism; Special Autonomy Law; Migration; Conflict; Sustainable Development

\section{INTRODUCTION}

Since the implementation of special utonomy law,UU No. 45. Tahun 1999 and Inpres No. 1 Tahun 2001, identity to be the natives of West Papua becomes important to access power, to gain influence and to control over resources. Accordingly, status and identity as natives are exercised and challenged. To strenghthen the status as the natives, the capability to speak in local language and to tell the story about the origin of the ancestor is essential as it gives significant advantage over the conflict regarding identity. In addition, the magnitude of social struggle is likely to be related to conflict derived by domination to maximize profit and position of a group. In this case, Power relations are not reducible to class relations and both class relation and class struggle are crucial to social system because class struggle is the important embedded property of social system in which the profits and the power of one class is determined by the capability to maximally exploit and to dominate other classes.

The struggle and claim over the rights as the natives of the land is in fact reflected on the Sougb and Wepu community inhabiting Sougb Jaya District, Teluk Wondama Regency. In fact, the struggle and social movement of Sougb and Wepu clans to position and to strengthen their status as one of the indigenous clans of Teluk Wondama Regency have been maintained and nurtured for a series of decades. This is feasible as they are married with the natives of Kaprus. In addition, the position of Sougb and Wepu becomes stronger because the natives of the Sougb Jaya District, the Wondama people, gradually leave the village leaving the Sougb and Wepu as the majority of the district.

\section{RESEARCH METHOD}

As the main goal of the research lies on the analysis of the formulation of identity as natives, language use and the social movement, the method used is snowball sampling, interview, ethnography and participatory observation. Snowball sampling is utilized to effectively obtain the valid information and to make sure that the respondents interviewed are qualified. In this case, the head or the senior of each clan from Sougb, Wepu and Wondama is interviewed to obtain the data related the social movement and the language they use in formal and informal domain. Points out that the approach to scrutinize the language used by particular community to communicate with other communities can be done by combining sociolinguistics and anthropology so that the approaches used are interview and participant observation (the researcher blends with the community to do analysis and observation on their daily life) [1]. In addition, the mode of interview is structured interview in which the list of open questions is systematically ordered to be answered by the respondents. In addition, the observation is implemented to closely scrutinize the daily life of Sougb and Wondama people

\section{RESULT AND DISCUSSION}

The section is devoted to discuss the migration of the tribes, social movement of major clans together with the minor clans. The strategy of the major clan to strengthen their position through reproduction of myth, language use and social movement to control villages in Sougb Jaya District..

\section{A. Description of Sougb Jaya District}

There are actually 5 villages under Sougb Jaya District. They are Kaprus as the capital, Siresi village, Nuspairo village, Reyob village and Yarmatum village. The total population is 591 people that compose 239 family units (BPS Teluk Wondama, 2015). These 5 villages are categorized as "swadaya" village; it is a village that is able to self sustain 
basic needs and is strongly rooted in culture and traditional values.

The economy of Sougb Jaya District is motorized by 7 kiosk owned by the new-comers from Buton and Bugis. In this case, the trade takes place between the owners of the kiosk and the local villagers because the products such as fresh fish, salt fish, and sea cucumbers are sold directly to all the merchants (kiosk owners). Moreover, the villagers also have livestock (pig) that they sell to the buyers from Prafi, Manokwari Regency and Bintuni Regency. It is clearly reflected on the numbers of livestock in Sougb Jaya in 2015 that is dominated by pig at approximately 146 in 2014 (BPS Teluk Wondama, 2015). The villagers also get income from selling the harvest from their garden or farm and compensation from logging company that conducts logging activity in communal or clan property. In terms of the social system, all villagers are bounded by the relationship resulted from marriage. Marriage in this case combines and strengthens the tie of two or more extended families.

\section{B. Special Autonomy in Sustainable Development Plus Perspective}

In the light of sustainable development plus, special autonomy and "Pemekaran" (opportunity to establish new administrative area such as province and district) are less efficient in dealing with the core of sustainable development plus. Sustainable development plus comprises of two main elements: the core and the external layer. The core consists of interest to be on better position, alliance, engagement, adoption and security, while the external layer comprises of social, economy, environment, empowerment, governance and stewardship [2]. This model is based on the paradigm that choice and course of action are driven by the interest to be on better position. The interest is extended and exercised by alliance with party who shares the same interest. The alliance evaluates the interest by engagement with the opponents and the environment. From the engagement process, there is process of adoption of product, idea and behaviour in order to achieve collectivity. The collectivity can support security at spiritual and material level.This core is then extended into social, economy, environment, empowerment, governance and stewardship layers.

Special autonomy law legalized in 2001 has ultimate goal to improve the welfare of the West Papuans and to put West Papuan in better position through the implementation of decentralization. Special autonomy and "Pemekaran" (opportunity to establish new administrative area such as province and district) aims at delivering "papuanization".

However, it is crippled in two areas namely legal basis, social basis and unity basis. The legal basis is related to the fact that Provincial regulation (Peraturan Daerah Provinsi) and special region regulation (Peraturan Daerah Khusus) are not legalized yet. As a result, the government cannot function maximally. In addition, for the social basis, the special autonomy has bad image for some West Papuans. It is considered as "blood money"; the money given to West Papua because West Papua asks for independence or the money given to West Papua for the human casualties during military operation. The unity basis is related to the fact that special autonomy indirectly create gap between West Papuans and non West Papuans, and between West Papuans (natives of particular area /"Orang Asli") and West Papuans (non natives of particular area).

As special autonomy goes hand in hand with policy regarding further establishment of new province and districts (Pemekaran), it leads to "worship of ethnicity". It creates segregation and separation as the natives of particular area (Orang Asli) asks for prioritization. As an illustration, the natives of Manokwari, the Arfak tribe, can ask for prioritization in the recruitment of civil servants. They also differentiate themselves from other West Papuans with the term "Orang Asli" (the natives of the land). In addition, the "adat" institution becomes powerful actor since they have bargaining capability with the government and the "adat" rules are also applied in some cases including access and control over land. Therefore, the special autonomy law that enables prioritization program from government through affirmation program, and the spirit to establish new province, regency and districts have nurtured worship of identity and interest to be on better position.

\section{Migration of Clans to Sougb Jaya District}

In relation to migration, subject right is related to the capability to protect and to maintain the right as the owner of the land. Object right is related to resource above and below the land that is either wanted or not wanted and it influences the willingness and the capability of mobilization. The kind of right is right embedded on a group of people or state to arrange and to regulate the mobilization on particular area. Therefore, the reasons of migration are losing ownership and control over land (subject right), pursuing scarce resource and escaping from harmful resource (object right) and bundle of rights embedded in state, community, family and individuals.

Kaprus, the capital of Sougb Jaya District, is the melting pot of clans from Wamesa and Sougb. It is the place where Nukom, the leader of Kaikatui clan, build the settlements and it is also the place where other clans such as Bokoma, Sayori and Tubes get protection from their assassins. From the history of the clan, it is clear about the original place of Wepu Clan, and Sougb clans (Bokoma Clan, Tubes Clan, Arhita Clan, and Iba Clan), and there are reasons that drive the clans to migrate to Kaprus. The reason of Iba, Tubes, Arhita, Ista,and Bokoma clans to migrate to Kaprus is because of conflict. The fierce conflict ends with the condition in which these clans lose control and ownership over their land. Especially for Arhita, they become target of assassin (Suanggi) so that they change their family name into Mokiri. Moreover, there are some Kaikatui clans that migrate from Kaprus to Yombekiri and Yomakan because of conflict with Bokoma and Sayori clans. They are outnumbered by other clans such as Wepu, Mokiri and Sayori. The spirit of locality, and nativity is capitalized by special autonomy and the implementation of UU No. 45. Tahun 1999 dan Inpres No. 1 Tahun 2001. The regulation and law are likely to endanger the position of Sougb and Wepu clans because they are the migrants in Sougb Jaya District. Fortunately, they can reconstruct their identity as the natives because: first, Kaikatui clan, the natives of Sogb Jaya District 
is fragmented by conflict resulting in the migration of a large number of families to Yombekiri and Yomakan. Second, The leaders of Sougb and Wepu clans are multi-language; They are able to use Wamesa language and Sougb language. Utilization of Wamesa language in formal domain effectively strengthens their position as the natives. Third, The leaders of Sougb and Wepu are able to reproduce myth about their origin and it is believed by the members of the clan. Fourth, The leaders of Sougb and Wepu are successfully managed the social movement and are able to be the village leaders in Soub Jaya District. Finally, The leaders of Sougb and Wepu clans successful create the name of district (Sougb Jaya) which represents their identity as the natives. Sougb Jaya District used to be part of Rumberpon District; it is then established as new district on June 2008.

\section{Myth and Reproduction of Identity}

Myth as a story, message and compass for mind and action varies based on the nature, people and community where the myth is nurtured and told. Straus mentioned that myth is related to the dynamic of human mind that is actively engage with the environment to set up logical coherent system, and human mind interacts with many different kinds of environment integrated into the ideology system that give boundaries and limitation to mentality. According to Mircea Eliade, myth can be defined into myth about cosmos, myths about origins, myths about gods and great deity and androgen myths, and myths about the end of the world [3].

There are four versions of myth about the origins of Sougb and Wepu clans in Sougb Jaya District. This is related to the fact that leaders and elders of Sougb, Wepu and Wamesa clans do not have same story and same message. It is clear that interest to be on better position shapes the message of the myths. Firstly, It is stated that the ancestor of the Wepu tribe is Mambarupi Mokiri. He once assigned the guardians namely Yaimeki to protect the holly tabernacle (Sara) in Botak mountain while Makekoni has obligation to protect holly tabernacle in the river of Warsumbou. One day, Mambarupi visited both of them and found out that both of them committed adultery with their own sisters. Consequently, they are expelled out; Yaimeki then moved to Dusner and developed the Sayori clan while Makekoni moved to Wombo/ Naikere and developed Bikai clan. Mambarupi then leave Mapar Mokiri and did a journey and explored some places namely Bambu island, Yendumat, Yomakan, and finally settled in Kaprus. Kaprus at that time is no man land, and Mambarupi then established settlement in Kaprus. His arrival in Kaprus is then followed by waves of migration from Bikiai clan, Sayori clan and Kaikatui clan to stay at Kaprus.

Secondly, Bikiai means a person on the right side. In the beginning, the Bikiai clan occupied Yaimeki Mountain. However, because of conflict, they are then forced to move to Runaki cape. In addition because of marriage between Kaikatui clan and Bikiai clan, they then stay at Kaprus.Thirdly, Sayori clan is descendant of Sinta/ Wepu tribe that lives on Isim high land. Sayori is in fact the name of the mountain on Isim high land. The ancestor of Sayori clan is Jom. Jom has one son named Mambo and two daughters named Miera and Tebrero. The Mokiri clan is in fact established from the blood line of
Jom. Tebrero bear a son named Mahiro. Mahiro has a son named Jombri and a daughter named Tisupa. Jombri has a son named Jupter. Tisupa has two sons named Kaleb Sayori and Set Sayori. Set Sayori has a son named Wellem Sayori, Barnadus Sayori, Yulianus Sayori and Yulius Sayori. Miera then got married with Sukotmetko from Ista. They got a son named Icara. He got two sons named Ub and Rotjum. Ub got married with Suku Ita from Ista and they got a son named Simon Sayori. In addition because of living on the highland, the main source of protein is rat and this is exacerbated with conflict. Miera asked Icara to move to the coastal area and some Sougb clan also moved to the coastal area. After moving to the coastal area, the Ub descendants changed their identity to Sayori as their clan.

Final version is that Wepu or Befu tribe is actually the collaboration of three major clans namely Mokiri, Sayori Wepu dan Bikiai. This tribe originally occupied the high land of Mokiri and then they moved to the south and they then arrived at Wamsiru. They then stayed there temporarily and moved to Bambu Island. From the Bambu Island they moved to the north and they approached Yendumat. Since the World War II hit Papua, they then moved to Yomakan and lived together with Kaikatui clan. After the Worl War II, they returned to the Bambu Island. Then, Yohanes Mokiri left Bambu Island and settled down at Worparen River in Kaprus. He then asked his entire clan to live with him. At that time, the Kaikatui clan occupied Kaprus. As there is missionary who spread the values of Christianity, a church is then built in Kaprus. The Mokiri clan and the Kaikatui clan are heavily influenced by Christianity values and they then become Christians. Because of this, the Mokiri clan lived together with the Kaikatui Clan in Kaprus because there is only one church; the church is only found in Kaprus.

\section{E. Social Movement and Reproduction of Identity}

Social movement can be defined as the systematic way of action in implementing and nurturing the strategy and series of coordinated movements to achieve and to secure the interest of a particular group. Christiansen [4] pointed out that there are four stages of social movement namely: emergence (very preliminary social movement with little or no organization), coalescence (organized collective movement with strategy), bureaucratization (higher level of organization that based on coalition strategy), and decline (incapability to deal with obstruction associated with success and constraints of organization). In addition, the social movement might be associated to the fear and threat from external group. Bloch [5] mentioned that the importance of the in-group is intensified because there is a threat imposed from another out-group. Moreover, the social movement stages are reflected clearly on the social movement initiated by the Sougb and Wepu community in Kaprus. In order to analyze the social movement, the dimension of ethnic is needed to be scrutinized. Oliver [6] mentioned that "the three groups of ethnic dimensions are the vertical dimension of structures of domination, the horizontal dimension of network ties and network cleavages and the temporal dimension of intergenerational transmission and these three dimensions are the analytic tools for characterizing the social location of any 
group so that any theory of social movements needs to pay attention to these dimensions as part of its analysis".

The coalescence can be analysed from the vertical, the horizontal and the intergenerational transmission dimension. In terms of the vertical dimension, it is executed as the Kaikatui clan is weak due to conflict and massive migration to other places. This is depicted as the Mokiri clan succeeds to be the head of the village at the capital of Sougb Jaya. This is then permanently strengthened and established by formulation of rule that the head of the village should be from the descendants of Mokiri clan. Moreover, the horizontal dimension is obvious in the development of allies. As explained on the history of the clan, there are several clans such as Bokoma, Tubes, and Iba that are allowed to live in District Sougb Jaya by the Mokiri clan. This is then strengthened by being able to communicate in Wamesa language and inter clan marriage with their allies: Tubes, Sayori, and Bokoma. As an example, it is recorded that the wife of the head of BAPERKAM is from Mokiri clan. In terms of the intergenerational transmission dimension, the Mokiri clan tries to establish themselves as the superior clan.

The strategy used to strengthen their position is done by establishing the allies in time of crisis (conflict), and reformulating the myth. In this case, the Mokiri clan claims themselves as the first clan that establishes their settlements and develops Kaprus. They also claim that they get the right as the eldest clan of Kaprus. This is supported by the head of four clans that live in Kaprus village namely the Bokoma clan, the Tubes clan, the Sayori Clan, the Werianggi clan as well as the head of two clans that live outside Kaprus village: the Arhita clan and the Iba clan. In contrast, the head of Kaikatui and Bikiai clan believe that the Mokiri clan is not suitable as the head of the Kaprus village. The Kaikatui clan does not support the Mokiri clan as the head of the village as they are the first tribe that establishes and develops Kaprus. In adition, the Bikiai clan believes that the Bokoma clan is more capable as the leader of the village. The conflict regarding the nativity, the superior status, and ownership of Sougb Jaya is won and controlled by Mokiri and its allies.

In addition, the intergenerational transmission dimension deals with the capability of the Mokiri clan to doctrine and to earn acceptance about their version of clan history especially from their young generation and from their allies (Bokoma clan, Tubes clan, and Iba clan). The bureaucratization stage is the naming of the district as Sougb Jaya. It clearly legalizes that the indigenous people are the clans from Wepu tribe (Mokiri, Sayori and Bikiai) as well as the clans from Sougb tribe. Accordingly, the position of Kaikatui clan is minimized.

Moreover, the utilization of Sougb as the new name of the District is due to the fact that the district is majority inhabited by the Sougb tribe. The table below explains the distribution of clan in the five villages under Sougb Jaya District.

\section{F. Language Use and Reproduction of Identity.}

The language use of the clan leaders in Kaprus village is likely to be closely related to the interest to be in better position in economic, social, and political spheres. This interest is in fact triggered by the special autonomy law and further establishment of district and regency (pemekaran) that prioritizes freedom and opportunity in social, economic, politic and development program to the natives based on their locality. The context of language used in Kaprus village, motives behind the use of Wamesa language, the power of Wamesa language and Sougb Language, and the utilization of Wamesa language in formal and informal domain are then explained to obtain better understanding about the worship of identity in Kaprus.

Wamesa is one of Austronesian language spoken in Wondama Bay area (Gleevink bay), the South West coast of Papua Barat Province in which it is positioned in the south and east of the Bird's head region to the end of Bintuni Bay [7]. The speaker of this language is now residing some areas including Teluk Wondama, Teluk Bintuni, Fakfak and Kaimana Regency [8]. Wamesa language has SVO word order and it has three dialects namely Windesi, Wandamen and Bintuni. In this case, the dialect spoken in Sougb Wepu District including Kaprus village is Windesi.

Kaprus village is the melting pot of two big ethnic namely The Sougb tribe and the Wamesa Tribe. The implementation of 'pemekaran' and special autonomy law significantly change the social class of the Sougb tribe; they are the natives of Papuan but based on the locality, they are not the natives of Kaprus village. Accordingly, their position might not be accommodated by the 'pemekaran' law. As a result, they try to establish their new identity as the the native of Kaprus village. This is executed brilliantly by the re-creation and reformulation of their clan history. Other strategies implemented include the change of District name from Kaprus (Wamesa language) into Sougb Wepu to strengthen their position. This is not difficult, since the population of Sougb in Kaprus outnumbers the population of Kaikatua clan (Wamesa tribe) that is only 2 family units. Also, they dominate the position on village elite and use Wamesa language as the way to communicate with Wamesa people. This is in fact not difficult, as the migration of the Sougb tribe to Kaprus has been done in the past and they have lived with the Kaikatui clan that is able to speak Wamesa language, so that the descendants of Sougb tribe are bilingual because they are able to speak Wamesa, Sougb and Malay Papuan. In the past, they are the new comer to Kaprus (minority), the use of Wamesa language is a must to avoid the revenge and vendetta from their enemies. Mentions that the success of the minority to learn the language of the majority depends on instrumental motivation (language is perceived as instrument to achieve a goal), and integrated motivation (language is perceived as the important element that determines life in the future).

Coates [9] points out that the concept of social network $\mathrm{s}$ one of the productive concept in linguistic and it consists of closed network (strong language norm enforcement mechanism and high density group as they know each other) and open network (weak language norm enforcement mechanism and low density as the contacts are not related). As a result, the language norm enforcement mechanism might be easily executed by the leader of Mokiri clan as the superior leaders of Bikiai, Sayori, Tubes, and Bokoma clan. 
There are several reasons that motivate the leaders from Sougb tribe/ clan (the leader of Mokiri Clan, the leader of Bikiai clan, the leader of Bokoma and the leader of Tubes clan) to use Wamesa language. First, using Wamesa language might strengthen their position as the natives of Kaprus village due to special autonomy and 'pemekaran' implementation. States that language use is related with the social class, and the movement from class to class in social class is possible because social class is not fixed social strata likes caste. Secondly, the Wamesa language is more powerful than the Sougb language. The influence direction of the interaction of two languages depends on prestige and the benefits of use a language in social, economic, culture, politics, and religion, loyalty of the speakers, power of the speaker in social, economy, culture, politics and government, and national mobilization as well as national communication system and mass media, so that if the speakers of A language has better status of those 4 elements than the speakers of B language who live close to them, the influence direction moves from $\mathrm{A}$ to $\mathrm{B}[10]$.

In this case the change of direction of interaction of Wamesa language and Sougb language moves from Wamesa language to Sougb language because using Wamesa language improves the Sougb leaders position in politic, economy, culture, and identity as natives. Accordingly, they are forced to be loyal user of Wamesa language that supports their movement and mobilization to blend with other Wamesa tribes in Teluk Wondama Regency. Moreover, analyses that the power of language can be measured through several indicators: economy (Gross National Product of a country), ideology (function of language in nurturing ideology such as religion, politics and other particular belief) and culture (function of language in sustaining the richness of particular culture of community).

\section{CONCLUSION}

In short the reproduction of migrants in Sougb Jaya district is a phenomenon triggered by regulation (special autonomy and "Pemekaran") issued by the government. The openness of the community is clearly shown since the community especially the Sougb and Wepu clans are influenced by the regulation. The clans are able to engage, and deal with the regulation by strategically reconstruct their identity so that they can still get the prioritization and obtain the benefits of Papuanization. In fact, the identity reconstruction carried out by Sougb and Wepu clan is assisted by the inter-mariage with Wamesa clan, capability to speak in Wamesa, and successful leadership in crafting new myth and in mobilizing the allies to control the capital of Sougb Jaya with all the neighbouring villages. The reconstruction of identity, ethnocentrism, discriminating, conflict, and fragmentation are also cause by less effectiveness in implementing sustainable development concept that is in line with the social, economy and political condition of Papua. The sustainable development plus is offered as the solution because it addresses experience and learning process over the land, the people and the calling of Papuans.

\section{ACKNOWLEDGEMENT}

The research is funded by Department of Planing and Development. Teluk Wondama Regency, West Papua, Indonesia.

\section{REFERENCES}

[1] Sumarsono, Sosiolinguistik, Pustaka Pelajar, Yogyakarta, 2008.

[2] Huwae, M. Migration, Worship of Ethnicity and Special Autonomy Law, A case study of West Papuans in Kaprus, Teluk Wondama, Proceeding at IRSA conference, Bali. 2015

[3] Suryawan, I. Finding the Morning Star Etnography Fragments (Mencari Sang Kejora Fragmen-Fragmen Etnografi), Kepel Press, Yogyakarta, 2015.

[4] Christiansen, J. Social Movement and Collective Behavior: Four Stages of Social Movement, EBSCO Research Starter, 2009, pp.1-7.

[5] Bloch, K. Social Movement Framing and the Reproduction of Inequality: Immigrant Restrictionists Constructing Virtual Selves on the Internet. North Carolina State University. 2009.

[6] Oliver, P. 2013. The Ethnic Dimensions: Bringing Ethnic Divisions and Conflict to the Center of Social Movements Theory. Retrieved October 1 2016, from http://www.ssc.wisc.edu/ oliver/PROTESTS/ArticleCopi es/Oliver_The\%20Ethnic\%20Dimensions_Feb_2013.pdf

[7] Karubuy, T. Verbal Morphology in Wamesa Language. Sarjana Sastra Skripsi. State University of Papua., 2011.

[8] Kandami,Y.Subjective and Objective Personal Pronoun of Wamesa Language. Sarjana Sastra Skripsi. State University of Papua, 2010.

[9] Coates, J. Women, Men and Languages: Studies in Language and Linguistics, Longman, Essex, England, 1986.

[10] Jendra, IW. Sosiolinguistik Teori dan Penerapannya, Paramita, Surabaya, 2007. 